\title{
Tireóide ou Tiróide
}

Prezado Kater,

$\mathbf{E}$ SPERANDO COLOCAR MAIs "lenha na fogueira", encaminho a minha contribuição a respeito da discussão: tireóide ou tiróide.

Em 1909, foi publicado pela livraria Francisco Alves: em Belo Horizonte, Rua da Bahia 1909, em São Paulo, Rua de São Bento 65 e no Rio de Janeiro, Rua do Ouvidor 166 (endereços que provavelmente não existem mais) o livro do autor Ramiz Galvão denominado Vocabulário Etymologico, Orthographico e Prosodico das Palavras Portuguezas derivadas da língua grega (grafia da época).

Na página 574 (respeitando a grafia original) encontramos:

THYREÓIDE, s.f.(anat.) cartilagem situada na parte antero-superior da laringe, semelhante a escudo.

Nos livros e lexicos antigos davam thyroide; mas já Littré advertiu com acêrto que isso se deva corrigir.

Deriv.: thyreóideo (adj), thyreoidite (s.f.), thyreoidismo (s.m.), thyreoidina (s.f.)

Obs.: possuo uma cópia do livro gentilmente cedido pelo Prof. Dr. Roberto Alvarenga, eminente médico patologista ao qual agradeço.

Atenciosamente,

do colega endocrinologista de Belo Horizonte,

Endereço para correspondência:

José Côdo Albino Dias

Rua Paraíba 966 - sala 905

30130-141 Belo Horizonte, MG

e.mail: cododias@hotmail.com 